\title{
Feeding Systems and the Physicochemical and Sensory Quality of Lamb Meat: Can Feeding Systems Affect Lamb Meat Quality?
}

\author{
Geisa Costa (Corresponding author)
}

Graduate Program in Agronomy, Federal University of Parana. Rua dos Funcionarios, 1540, Curitiba, Paraná, Brazil. (+55) 41 99108-4966. E-mail: geisa_costa@hotmail.com

Renata Ernlund Freitas de Macedo

Graduate Program in Animal Science, School of Life Sciences, Pontifícia Universidade Católica do Paraná, Rua Imaculada Conceição, 1155, Curitiba, Paraná, Brazil, (+55) 41 98769-8087. E-mail: renata.macedo@pucpr.br

Fernando Hentz

Graduate Program in Agronomy, Federal University of Parana. Rua dos Funcionarios, 1540, Curitiba, Paraná, Brazil. (+55) 41 99131-0692. E-mail: lelopzo@gmail.com

Odilei Rogerio Prado

Universidade Tuiuti do Paraná. Rua Sydnei Antonio Rangel Santos, 238, Curitiba, Paraná, Brazil. (+55) 41 99986-7431. E-mail: orpradovet@gmail.com

Claudio José Araujo da Silva

Graduate Program in Agronomy, Federal University of Parana. Rua dos Funcionarios, 1540, Curitiba, Paraná, Brazil. (+55) 41 99826-9385. E-mail: claudiojaraujosilva@gmail.com

Cesar Augusto Taconeli

Applied Statistics Laboratory of the Federal University of Parana, Avenida Coronel Francisco Heraclito dos Santos, 210, Curitiba, Paraná, Brazil. (+55) 41 3361-3573.

E-mail: taconeli@ufpr.br

Alda Lúcia Gomes Monteiro

Department of Animal Science, Sheep and Goat Production and Research Center, Federal University of Parana, CNPq Research Fellowship. Member of the MARCARNE network, funded by CYTED (ref. 116RT0503). Rua dos Funcionarios, 1540, Curitiba, Paraná, Brazil. (+55) 41 99972- 6444. E-mail: aldaufpr@gmail.com 
Ml Macrothink

Received: August 22, 2019

doi:10.5296/jas.v7i4.15500
Journal of Agricultural Studies

ISSN 2166-0379

2019, Vol. 7, No. 4

Accepted: Sep. 18, 2019 Published: Sep. 23, 2019

URL: https://doi.org/10.5296/jas.v7i4.15500

\begin{abstract}
This study aims to evaluate the physicochemical characteristics, fat composition, and sensory attributes of lamb meat produced in two feeding systems: (1) Unweaned and unsupplemented lambs in the pasture and (2) early weaned lambs in the pasture with concentrate supplementation post-weaning. The experiment was performed in the winter-spring pastures in the subtropical region of Brazil. The experimental design was completely randomized with two treatments (feeding systems), four paddocks per treatment and twenty lambs (experimental units) per paddock. Carcass weight, dressing percentage, $\mathrm{pH}$, rib eye area, subcutaneous fat thickness, and visual fatness were determined. Loin samples were used for instrumental color, thawing and cooking loss, shear force, water holding capacity, fat and sensory analyses. Carcass $\mathrm{pH}$ did not differ between the systems $(p>0.05)$. Supplemented weaned lambs showed a higher body condition score, carcass weight, dressing percentage and fatness $(p<0.001)$. They also showed higher $(p<0.05)$ total fat and long chain fatty acid (FA) content than unweaned lambs. Lamb meat from both systems showed similar and high sensory acceptance. Early weaning and supplementation proved to be a better choice for producing lambs in the winter-spring pasture, under subtropical conditions, because it promoted better carcass and meat traits and good sensory attributes, which could improve payment to the farmers.
\end{abstract}

Keywords: fatty acids, lamb production, sensorial analysis, pasture, ruminant

\title{
1. Introduction
}

The consumption of ruminant meat products has greatly increased in developing countries such as Brazil. Some aspects of lamb meat production may be considered such as the profitability to the farmer, safety to human consumption and the high quality with low environmental impact.

Different sheep production systems are used worldwide, which offer different types of handling and determine differences in the characteristics of lamb meat (Sañudo et al., 2007). In countries with the greatest commercial lamb production, such as New Zealand, sheep are produced almost exclusively on cultivated pastures, with very few concentrates (Morris and Kenyon, 2014). In Brazil, lamb meat is mainly produced using pastoral production systems in commercial herds, made up of dual-purpose and specialized breeds for meat production (Ricardo et al., 2015).

Most of the Brazilian sheep herds are in the Southern and the Northeast biomes, in extensive areas. However, in agricultural and integrated livestock crop production areas, farmers have intensified lamb production to slaughter younger animals. In this case, intensive grazing systems, concentrate supplements, and feedlot strategies are used.

One of the intensive systems is a very simple technology: No weaning lambs in pastures until 
the slaughter weight and considering high herbage allowance for the lactation ewes. In this case, it was noted that favorable profitability and animal welfare (Fernandes et al., 2014). Another production strategy in intensive livestock areas is early weaning of lambs (60 days old) and feeding them post-weaning concentrate supplements in pastures until slaughter. In this case, because of a higher protein intake (Houdijk, 2012), the ewes are ready for new mating and earlier and rapid lamb growth cycle takes place (Fernandes et al., 2010; Ribeiro et al., 2009), with lower parasitological challenges (Salgado and Santos, 2016).

Feeding systems that promote adequate fat levels, lower concentrations of saturated fatty acids, and acceptable sensory characteristics of meat are of great interest to farmers, industries, and consumers (Montossi, 2007).

Thus, we aim to study the physicochemical characteristics, the FA profile, and the sensory attributes of the carcass and meat of lambs produced in two feeding systems in an integrated livestock crop production area, in the subtropical region of Brazil. We hypothesized that different feed sources can modify the quality of the lamb's meat, including the profile of FA, towards greater commercial quality and higher nutritional value.

\section{Material and Methods}

\section{Ethics statement}

The animal handling procedures were approved by the Ethics Committee on Animal Use, Federal University of Paraná (UFPR), Brazil, protocol number 052 / 2011.

The ethical and biosafety aspects of the sensory analysis were approved by the Research Ethics Committee (CEP) of PUCPR (Pontifícia Universidade Católica do Paraná, Brazil) under protocol number 1.072.008.

\section{Experimental area, treatment, and animals}

This study was performed at the Tangará Commercial Farm, in the Southern Region of Brazil ( $\left.24^{\circ} 38^{\prime} 58^{\prime \prime} \mathrm{S}, 50^{\circ} 51^{\prime} 03^{\prime \prime} \mathrm{W}\right), 833 \mathrm{~m}$ above sea level. The climate is subtropical $\mathrm{Cfb}$, according to the Köppen-Geiger climate classification. The experiment lasted 81 days in the winter-spring season.

Forty Ile de France male lambs were allocated to two feeding systems (20 lambs for each feeding system): (1) Unweaned and unsupplemented lambs in pastures until slaughter $(\mathrm{n}=20)$ and (2) early weaned lambs from pastures with concentrate supplementation post weaning, at $2 \%$ body weight per day, until slaughter $(\mathrm{n}=20)$. Thus, lambs were milk-fed (suckling lambs) with free access to the pasture in system 1; the weaned lambs had pasture-grazing and concentrate as sources of nutrients, in system 2 .

Sixteen lambs were twins and four lambs were single birth, in each treatment. Unweaned lambs presented a mean $( \pm \mathrm{SD})$ initial body weight $(\mathrm{BW})$ of $21.7 \pm 3.23 \mathrm{~kg}$ and weaned lambs, a mean $( \pm \mathrm{SD})$ initial $\mathrm{BW}$ of $19.6 \pm 5.45 \mathrm{~kg}$. The mean $( \pm \mathrm{SD})$ initial age of the lambs was $61.0 \pm 4.7$ days. Ewes presented a mean initial $\mathrm{BW}$ of $67.0 \pm 1.8 \mathrm{~kg}$ and were not supplemented during the experiment. 
The pasture was of annual ryegrass (Lolium multiflorum Lam.) overseeded on perennial Tifton-85 (Cynodon spp). The grazing method was continuous and variable stocking according to the "put and take" technique (Mott and Lucas, 1952), adjusted every 21 days to keep the herbage allowance of $12 \mathrm{~kg}$ dry mass (DM) / $100 \mathrm{~kg}$ body weight (BW) / day (12\%). A 6.0 ha area of cultivated grassland was subdivided into eight grazing paddocks. For weaned and supplemented lambs, the paddock area was 0.35 ha and for unweaned lambs and ewes was 1.1 ha.

The concentrate feed for weaned lambs (Golden Sheep Cordeiros e Borregos®; Agraria Ovinos; $20 \mathrm{~g} / \mathrm{kg}$ Crude Protein) was offered ad libitum, daily in the afternoon (4:30 pm) at $2 \%$ of BW (body weight) in DM / day. The diet was formulated to meet the requirements of weaned lambs with fast growth potential (NRC, 2007). The adjustment of concentrate was performed every 21 days, when the animals were weighed after 12 hours of solid fasting. The mean concentrate intake during the experiment was $520 \mathrm{~g} /$ day.

\section{Forage and concentrate analysis and nutritive value}

Hand plucking method (Burms et al., 1989), that simulates the animals grazing, was used to collect the forage from pasture for chemical analysis every 21 days. The concentrate sampling was also done every 21 days. Samples of the pasture and the concentrate were analyzed at the Laboratory of Animal Nutrition in the Department of Animal Science of the Federal University of Paraná, Brazil. For the estimation of the total digestible nutrients (TDN), the formulas described by Kearl (1982) for the concentrate and Weiss et al. (1992) for the forage were applied. Total nitrogen was determined by the Kjeldahl method (AOAC 1984) and crude protein $(\mathrm{CP})$ was obtained by multiplying the total nitrogen concentration by 6.25 . Neutral detergent fiber (NDF) and acid detergent fiber (ADF) were determined according to Van Soest et al. (1991). The proximate composition of pasture and concentrate is presented in Table 1.

Tabela 1. Dry matter (\%) and proximate composition (\% DM) of pasture and concentrate in lamb feeding systems

\begin{tabular}{lcccc}
\hline & Unit & Tifton-85 & Annual Ryegrass & Concentrate* \\
\hline DM & $(\%)$ & 31.5 & 23.8 & 89.4 \\
TDN & & 64.0 & 74.0 & 83.0 \\
CP & & 12.6 & 17.9 & 19.8 \\
NDF & $(\% \mathrm{DM})$ & 59.0 & 58.0 & 20.9 \\
ADF & & 23.3 & 23.4 & 5.54 \\
Fat & & 3.7 & 4.1 & 2.7 \\
Ash & & 8.1 & 12.1 & 4.7 \\
\hline
\end{tabular}

*Concentrate ingredients: corn meal (40\% DM); soybean meal (40\% DM); wheat bran (15\%), $\mathrm{CaCO}_{3}(2.5 \% \mathrm{DM})$, common salt $(0.5 \% \mathrm{DM})$ and mineral salt $(2 \% \mathrm{DM})$.

DM: dry matter; TDN: total digestible nutrients; CP: crude protein; NDF: neutral detergent fiber; ADF: acid detergent fiber. 


\section{Carcass and meat quality evaluations}

The unweaned lambs were slaughtered (means \pm SD) at $37.4 \pm 3.97 \mathrm{~kg}$ and $143.8 \pm 6.31$ days old, whereas supplemented weaned lambs were slaughtered at $39.8 \pm 5.49 \mathrm{~kg}$ and at $144.2 \pm$ 7.58 days old. The lambs were fasted for 16 hours before slaughter, with free access to water. After that, the animals were weighed (slaughter weight - SLW) and the body condition score (BCS, 1-5 scale; Russel et al., 1969) was determined.

The slaughter was carried out in a commercial abattoir according to the Parana State Inspection System (SIP), Brazil. The stunning was made by eletronarcosis and bleeding by the section of the jugular veins and carotid arteries. After evisceration, the hot carcass weight (HCW) was taken; they were left for $6 \mathrm{~h}$ at $21^{\circ} \mathrm{C}$ ambient temperature and then transported to a cold room set to $4^{\circ} \mathrm{C}$ for $24 \mathrm{~h}$. Carcass characteristics were determined in 20 lambs from each treatment. Cold carcass weight $(\mathrm{CCW})$ was determined and the dressing percentage (DP) was calculated as follows: Hot carcass weight (HCW)/slaughter weight (SLW) X 100.

The visual fatness (VF) was assessed after carcass cooling using a subjective five-point scale, according to Caneque and Sañudo (2000), which indicates the amount and distribution of external fat in the carcass from 1 (lean) to 5 (very fat).

Carcass $\mathrm{pH}$ was determined at 45 minutes $\left(\mathrm{pH}_{45 \text { min. }}\right)$ and at 24 hours after slaughter $\left(\mathrm{pH}_{24 \mathrm{~h}}\right)$ (AOAC, 2000), using a portable digital potentiometer with penetration probe (Hanna Instruments HI 99163) in Longissimus thoracis and lumborum muscle (LM) penultimate rib (AOAC, 2000).

The carcass subcutaneous fat thickness (SFT) was evaluated between the twelfth and thirteenth thoracic vertebrae, using portable digital calipers, according to Caneque and Sañudo (2000).

The measurement of the rib eye area (REA) was performed on a cold carcass, on the LM, between the twelfth and thirteenth ribs (at the insertion of the last thoracic vertebra to the first lumbar). The REA was determined following the methodology described by Huidobro et al. (2000).

The carcasses were divided lengthwise taking up the loins on the left and right side, from the transverse cut between the 13th thoracic vertebra and the 1st lumbar vertebra and the 6th lumbar vertebra and the 1st sacral vertebra, according to Colomer-Rocher (1988). The loin samples $(\sim 200 \mathrm{~g})$ were vacuum packed in ethylene vinyl alcohol $(\mathrm{EVOH})$ packaging (permeability of $4 \mathrm{~cm}^{3} \mathrm{O} 2 / \mathrm{m}^{2}$ per day at $1 \mathrm{ATM}$ and $23^{\circ} \mathrm{C}$ ) and kept frozen at $-18^{\circ} \mathrm{C}$ until analyses. 36 left loins were used for physicochemical parameter determination (18 from each treatment) and the 36 right loins were used for sensory and FA composition analyses.

After 90 days of frozen storage, the loin samples were thawed under refrigeration until they reached an internal temperature of $2^{\circ} \mathrm{C}$ to $5^{\circ} \mathrm{C}$, and the thawing weight loss (TWL) was determined by gravimetry and expressed in percentage (Muela et al., 2010).

The meat instrumental color was determined after the total thawing of the loin samples. The analysis was performed through an average of five shots directly on the surface of the 
samples (approximately $3 \mathrm{~cm}$ thick), $30 \mathrm{~min}$ following the exposure of the sample surface to the atmosphere. The method specified by the American Society for Testing and Materials (ASTM) (2001) was used, with a portable spectrophotometer (Konica Minolta CM-600D, Tokyo, Japan), illuminant D65, and a $10^{\circ}$ observer.

The CIE Lab system for the reflectance of light was used in three dimensions: $\mathrm{L}^{*}$ represented the lightness and $\mathrm{a}^{*}$ and $\mathrm{b}^{*}$ represented the intensity of the red and yellow colors, respectively.

Cooking weight loss (CWL) was determined in samples (previously weighed) cooked in heat-resistant polyethylene bags in a water bath at an internal temperature of $70^{\circ} \mathrm{C}$ for 15 minutes (Morgan et al., 1993). After cooking, the samples were dried with absorbent paper and cooled at room temperature for reweighing. Cooking weight loss was expressed as a percentage related to the initial weight, determined by gravimetry (Pla, 2000).

The shear force $(\mathrm{SF})$ was determined in cooked samples ( $\mathrm{n}=5$ replicates), as previously described. They were cut in $1.27 \mathrm{~cm}$ cylindrical shapes, with a 2-cm length. The samples were sheared perpendicularly to the muscle fiber orientation by a Heavy Duty Platform (HDP) / 90 probe, in a texturometer TAXT2i (Stable Micro Systems, Surrey, England), equipped with a Warner-Bratzler blade. Shear force was taken with $1.5 \mathrm{~mm} / \mathrm{s}$ test speed and $30 \mathrm{~mm}$ distance from the base.

Water holding capacity (WHC) was assessed in accordance with Barbut's (1996) study and calculated using the following formula:

WHC $=100-$ [(Initial weight of sample - Final weight of sample / 100) x 100].

\section{Fat content and fatty acid profile}

For total fat content determination, 10 loins from each treatment were used. The samples were weighed in triplicate and subjected to extraction by the Soxhlet method (996.06) (AOAC, 2000). The FA composition was determined in accordance with Hartman and Lago (1973), in duplicate. The FA methyl esters (FAMES) obtained according to the method of Hartman \& Lago (1973), using ammonium chloride solution and sulfuric acid in methanol, as esterifying agent, were analyzed on a Varian 3900 gas chromatograph (GC) flame ionization detector (FID). A workstation with STAR software, split injector, sample split ratio of 75:1, and the CP-SIL 88 capillary column were used. The chromatographic conditions were: Programmed column temperature starting at $120^{\circ} \mathrm{C}$ for 5 minutes, raised to $235^{\circ} \mathrm{C}$ at $3^{\circ} \mathrm{C}$ per minute, and remaining at that temperature for 20 minutes. Hydrogen was used as the carrier gas at a flow rate of $1 \mathrm{~mL} /$ minute and nitrogen, make-up gas at $30 \mathrm{~mL} /$ minute, with injector temperature of $270^{\circ} \mathrm{C}$, detector temperature of $300^{\circ} \mathrm{C}$, and injection volume of $1 \mu \mathrm{L}$ (Firestone, 1998).

The FAMES in the total lipids of each sample were identified by comparing retention times with those of a standard FAME mixture (SupelcoTM 37 Component FAME Mix). The results were expressed in $\mathrm{g} / 100 \mathrm{~g}$ meat.

For sensory analysis ten loins were used, five for each treatment. The loin samples were 
cooked as described previously for CWL and cut into cubes of $\sim 2 \mathrm{~cm}^{3}$ and kept warmed (approximately $55-60^{\circ} \mathrm{C}$ ) for a maximum of 30 minutes. No flavoring was added to the meat at any evaluation time.

\section{Sensory analysis}

Sensory analysis was conducted only under the previous microbial innocuity evaluation of samples, according to the current Brazilian regulation (Brasil, 2001), related to the fecal coliform and Escherichia coli count and spoilage bacteria (count of psychrotrophic aerobic bacteria).

The samples were identified by three random digits and sensory assessed by a panelist of 133 untrained members (69 women and 64 men, from 18 to 50 years of age). Each panelist consumed four samples, two cubes of each treatment. The samples were presented to the panelists in a monadic order, to minimize the effect that the order would have on the responses (Sañudo Astiz, 2008). The sensorial tests were held in two days. Every day, in the morning, the samples followed the same pattern of preparation - an affective acceptance test with a nine-point hedonic scale $(1=$ 'strongly disliked'; $2=$ 'disliked'; 3 = 'moderately disliked'; 4 = 'slightly disliked'; 5 = indifferent; 6 = 'slightly liked'; 7 = 'moderately liked'; 8 $=$ 'liked'; $9=$ 'strongly liked') was used to evaluate how the panelists liked or disliked the color, tenderness, flavor, and overall taste of meat samples (Dutcosky, 2014).

\section{Experimental design and statistical analyses}

A completely randomized design with two treatments (two feeding systems) and 20 replicates (lambs) per treatment was used.

The data normality was checked by the Shapiro-Wilk test (Shapiro and Wilk, 1965). Analysis of variance was performed using the $\mathrm{F}$ test at a $5 \%$ significance level for the carcass and meat characteristics.

The Pearson's correlation was estimated for the body condition score (BSC), subcutaneous fat thickness (SFT), dressing percentage (DP), rib eye area (REA), shear force (SF), and visual fatness (VF). These variables are used for selection of animals for slaughter (specifically body condition score) and bonus for sheep farmers in the Brazilian commercial cooperatives. For the sensory data, the Wilcoxon nonparametric test was performed.

Data were analyzed using R software version 3.1.2 (R Core Team, 2012).

\section{Results and Discussion}

The feeding systems had no influence on meat $\mathrm{pH}_{45 \text { min }}$ and $\mathrm{pH}_{24 \mathrm{~h}}(p>0.05)$ (Table 3). Mean final $\mathrm{pH}\left(\mathrm{pH}_{24 \mathrm{~h}}\right)$ values varied from 5.50 to 5.56 for unweaned and supplemented weaned lambs, respectively, within the normal range reported by Young et al. (2004). 
Table 2. Means and standard errors of lamb carcasses characteristics in two feeding systems

\begin{tabular}{lcccc}
\hline Parameters & Unit & Unweaned lambs & Supplemented weaned lambs & P value \\
\hline SLW & $\mathrm{kg}$ & $37.4 \pm 0.88$ & $39.8 \pm 1.23$ & $\mathrm{NS}$ \\
BCS & 1 to 5 & $2.5 \pm 0.03$ & $2.8 \pm 0.02$ & $*$ \\
VF & 1 to 5 & $3.3 \pm 0.16$ & $4.0 \pm 0.11$ & $*$ \\
SFT & $\mathrm{mm}$ & $2.3 \pm 0.14$ & $3.1 \pm 0.13$ & $*$ \\
HCW & $\mathrm{kg}$ & $16.0 \pm 0.41$ & $18.0 \pm 0.60$ & $*$ \\
DP & $\%$ & $42.3 \pm 0.74$ & $46.4 \pm 0.61$ & $*$ \\
REA & $\mathrm{cm}^{2}$ & $12.0 \pm 0.41$ & $13.2 \pm 0.29$ & $* *$ \\
\hline
\end{tabular}

SLW=slaughter weight; BCS=body condition score; VF=visual fatness; SFT=subcutaneous fat thickness; $\mathrm{HCW}=$ hot carcass weight; $\mathrm{DP}=$ dressing percentage; $\mathrm{REA}=$ rib eye area.

$\mathrm{NS}=$ not significant $(\mathrm{P}>0,05) ; * \mathrm{P}$ value $<0.05 ; * * \mathrm{P}$ value $<0.01$

Feeding systems influenced $(p<0.05)$ BCS, HCW, DP, VF, SFT, and REA of the lambs (Table 2 ) with similar $(p>0.05)$ SLW. Supplemented weaned lambs presented higher HCW and DP ( $p$ $<0.05)$ than suckling ones, indicating higher muscle and adipose tissue development. Also, Boughalmi and Araba (2016) noted that when pasture feeding systems were predominant, lamb carcass yields were lower because the digestive tract was filled to the highest degree.

Similarly, REA was also higher $(p<0.01)$ for supplemented weaned lambs, confirming a greater muscle development in these animals. Although the LM muscle had late development (Owens et al., 1995; Hashimoto et al., 2012), it was observed that concentrate supplementation provided higher muscle deposition for lambs (mean 143-144 days old), which corresponded to an increased yield of high value meat cuts (Safari et al., 2001). These results agree with the study of Carvalho et al. (2006) and Carvalho et al. (2007), who found that a daily supply of concentrate equal to or greater than $2 \%$ of body weight for lambs would be sufficient to override the lack of milk and improve the performance of the animals.

The correlation matrix showed a positive correlation $(p<0.05)$ between DP and REA (Table 3 ), reaffirming the possibility of using the REA measurement by pre-slaughter ultrasound to choose the lambs with the highest carcass yield, as these will be better paid.

The BCS, VF, and SFT were also higher in the carcasses of supplemented weaned lambs (Table $2 ; p<0.05$ ). Diet is a factor that affects the carcass fat content and quality as it is directly linked with the energy intake (NRC, 2007). When ruminants ingest excessive energy, it is metabolized and stored as adipose tissue (Arruda et al., 2012). In our study, the concentrate fed to lambs - at $2 \%$ of BW (body weight) in DM / day — probably provided more energy than the other sources of nutrients (pasture and milk) and this caused the carcasses to have higher fat in them.

Also, the fat thickness can be influenced by increased carcass weight (Table 3). According to Chestnutt et al. (1994), fat depth increased by $0.52 \mathrm{~mm} / \mathrm{kg}$ carcass weight on a high nutrition plane compared to $0.13 \mathrm{~mm} / \mathrm{kg}$ on a low nutrition plane. 
Table 3. Pearson's correlations for the lamb body condition score, carcass characteristics and meat quality in two feeding systems

\begin{tabular}{|c|c|c|c|c|c|c|}
\hline Variables & SF & BCS & SFT & DP & REA & VF \\
\hline SF & 1 & & & & & \\
\hline BCS & -0.21 & 1 & & & & \\
\hline SFT & -0.12 & $0.63^{*}$ & 1 & & & \\
\hline DP & 0.01 & $0.57 *$ & $0.57^{*}$ & 1 & & \\
\hline REA & -0.05 & $0.5^{*}$ & $0.58^{*}$ & $0.65^{*}$ & 1 & \\
\hline VF & -0.19 & $0.66^{*}$ & $0.72 *$ & $0.64 *$ & $0.66^{*}$ & 1 \\
\hline
\end{tabular}

$\mathrm{SF}=$ shear force; $\mathrm{BCS}=$ body condition score; SFT=average subcutaneous fat thickness; $\mathrm{DP}=$ dressing percentage; $\mathrm{REA}=\mathrm{rib}$ eye area; $\mathrm{VF}=$ visual fatness

$* \mathrm{P}$ value $<0.05$

Besides that, BCS, VF, and SFT were positively correlated ( $p<0.05$; Table 3 ) meaning that a higher BCS resulted in superior carcass visual fatness and subcutaneous fat thickness (Sañudo and Sierra, 1986). The cooperatives of sheep farmers in Southern Brazil chose better lambs for marketing according to the BCS, at the pre-slaughter stage, thinking about the future carcass subcutaneous fat and superior quality of the meat cuts.

The meat SF was not affected by feeding treatments $(p>0.05)$ (Table 4). However, lamb meat from both systems can be considered as tender meat, with values ranging from $3.6 \mathrm{kgf}$ (supplemented weaned lambs) to $3.9 \mathrm{kgf}$ (suckling lambs) (Shackelford et al., 1997). The young slaughter age of animals (mean 143 - 144 days) must have contributed to the tenderness of the meat. Tenderness of lamb meat was also confirmed in sensory evaluation, as the tenderness scores were higher than 7.0 for both treatments (Table 7).

Sañudo et al. (1996) suggested that shear force and tenderness were significantly affected by carcass weight, which was not confirmed in this case. The Pearson's correlation matrix (Table 3) showed that tenderness of lamb meat was apparently not influenced by the fat and muscle content, nor by dressing percentage and feeding system.

Considering the other physicochemical parameters, feeding systems influenced the WHC and TWL $(p<0.05)$. The suckling lamb meat presented lower WHC and higher TWL (Table 4). The higher fat thickness in supplemented lamb carcasses could have protected them against water loss on cooling, as stated by Sañudo et al. (1997) and Fonseca et al. (2012). However, those differences were not high enough to affect the CWL and SF (instrumental) or sensory 
tenderness (Table 7). Similarly, Rizzi et al. (2002) also reported no difference in CWL in lamb meat from six different feeding systems.

Table 4. Mean and standard errors of physicochemical parameters of lamb meat in two feeding systems

\begin{tabular}{lcccc}
\hline & & & & \\
Parameter & Unit & Unweaned lambs & Supplemented weaned lambs & P value \\
\hline $\mathrm{pH}_{24 \mathrm{~h}}$ & - & $5.50 \pm 0.03$ & $5.56 \pm 0.27$ & $\mathrm{NS}$ \\
$\mathrm{WHC}$ & $\%$ & $69.03 \pm 0.45$ & $72.55 \pm 0.5$ & $*$ \\
$\mathrm{CWL}$ & $\%$ & $21.63 \pm 1.04$ & $20.33 \pm 0.87$ & $\mathrm{NS}$ \\
$\mathrm{TWL}$ & $\%$ & $4.89 \pm 0.37$ & $3.80 \pm 0.34$ & $*$ \\
$\mathrm{SF}$ & $\mathrm{kgf}$ & $3.9 \pm 0.22$ & $3.6 \pm 0.17$ & $\mathrm{NS}$ \\
$\mathrm{L}$ & - & $41.67 \pm 0.66$ & $43.17 \pm 0.89$ & $\mathrm{NS}$ \\
$\mathrm{a}^{*}$ & - & $15.23 \pm 0.45$ & $15.98 \pm 0.46$ & $\mathrm{NS}$ \\
$\mathrm{b}^{*}$ & - & $6.55 \pm 0.37$ & $6.34 \pm 0.45$ & $\mathrm{NS}$ \\
\hline
\end{tabular}

$\mathrm{WHC}=$ water holding capacity; $\mathrm{CWL}=$ cooking weight loss; TWL $=$ thawing weight loss; SF $=$ shear force $L^{*}=$ lightness; $a^{*}=$ redness; $b^{*}=$ yellowness

$\mathrm{NS}=$ not significant $(\mathrm{P}>0.05) ; * \mathrm{P}$ value $<0.05 ; * * \mathrm{P}$ value $<0.01$

The feeding system did not affect $(p>0.05)$ the instrumental meat color (Table 4) nor sensory color attribute (Table 7). The type of weaning (Sañudo et al., 1998a) and suckling can affect $\mathrm{L}^{*}$, redness $\mathrm{a}^{*}$, and hue in meat of light weight lambs (4 to $8 \mathrm{~kg}$; Panea et al., 2011). This effect was not observed in the lambs of the present study probably due to the higher slaughter weight and age of the lambs. Our lambs were 60 days old when sheep's milk production may be declining (Hentz et al., 2012). We must also take into account that the lambs in sucking system were milk-fed but with free access to the pasture as well. Osório et al. (2014) stated that in ruminants, the type of solid feed (pasture, cereals, grains) has low influence on meat color, possibly due to ruminal digestion.

The fatness characteristics of the carcasses (BCS, VF, SFT) were higher for supplemented lambs (Table 2) as the total FA content (Table 5). Meat from animals of both feeding systems can be considered "lean" according to the Food Advisory Committee (1990), as fat content is lower than $5 \%$. 
Table 5. Means and standard errors of the fat composition $(\mathrm{mg} / 100 \mathrm{~g}$ meat) of lamb meat in two feeding systems

\begin{tabular}{|c|c|c|c|}
\hline Composition & Unweaned lambs & Supplemented weaned lambs & $\mathrm{P}$ value \\
\hline Total fat content & $1087,00 \pm 160,82$ & $1638,00 \pm 227,58$ & $*$ \\
\hline Saturated FA & $607,00 \pm 83,39$ & $858,00 \pm 122,24$ & NS \\
\hline Monounsaturated FA & $443,00 \pm 71,52$ & $713,0 \pm 108,21$ & NS \\
\hline Polyunsaturated FA & $41,00 \pm 6,90$ & $44,00 \pm 6,18$ & NS \\
\hline
\end{tabular}

$\mathrm{NS}=$ not significant $(\mathrm{P}>0.05) ; * \mathrm{P}$ value $<0.05 ; * * \mathrm{P}$ value $<0.01$

The content of saturated (SFA), monounsaturated (MUFA) and polyunsaturated (PUFA) FA (Table 4) were similar $(p>0.05)$ in both treatments. Sañudo et al. (1998b) found higher polyunsaturated FA for suckling lambs than for weaned lambs, which was not confirmed for these feeding systems, but similar amounts of total unsaturated and total saturated FA.

In the present study, the MUFA content had no significant difference $(p>0.05)$ between the feeding systems. It would normally be expected that lambs receiving concentrated supplementation would present meat with higher MUFA content, considering that the concentrate has a higher content of MUFA compared to pasture. However, in both treatments lambs have grazed the same pasture (grasses) and the effect of grazing on meat FA composition depends on the forage species, as is the case of legume pastures (Lee et al., 2009). A MUFA content of 50\% was observed, while Alvarez et al (2013) reported $43.28 \%$ in lamb meat. The presence of this type of FA in the meat is important for consumers who aim to improve the lipid profile of the blood through the diet (Santos et al., 2013).

The concentrate feed (which is usually rich in linoleic acid) and ewes' milk absence did not affect $(p>0.05)$ the PUFA content of the supplemented weaned lamb meat. This result was expected because in ruminants a little portion of PUFA is available for incorporation into the tissues, because of the extensive biohydrogenation in the rumen, as detailed by Chikwanha et al. (2018).

Santos-Silva et al. (2002) stated that the FA profile of meat from lambs fed on pasture shows a better nutritional balance than of the lambs fed with concentrate because of the higher amount of n-3 polyunsaturated FA, higher concentration of conjugated linoleic acid (C18:2 n-6) and lower ratio n-6: n-3. In this case, the influence of feeding systems in the SFA composition was significant only for stearic acid (C18:0) content (Table 6). Stearic acid (C18:0) was greater in supplemented weaned lamb's meat. Enser et al. (1996) reported that high muscle concentrations of C18:0 are common in grazing animals, reflecting high levels of rumen biohydrogenation. However, despite being an SFA, this FA can promote a small reduction in low-density lipoprotein cholesterol (LDL-c) (Santos et al., 2013). Interestingly, 
Hunter et al. (2010) reported that increased intake of stearic acid (18:0) may have neutral or protective effect against cardiovascular diseases.

Table 6. Means and standard errors of FA profile (mg/100 g meat) of lamb meat in two feeding systems

\begin{tabular}{lccc}
\hline Fatty acids & Unweaned lambs & Supplemented weaned lambs & P value \\
\hline Myristic (C14:0) & $63,74 \pm 9,64$ & $55,60 \pm 8,82$ & NS \\
Palmitic (C16:0) & $313,26 \pm 46,07$ & $442,10 \pm 66,60$ & NS \\
Stearic (C18:0) & $229,83 \pm 29,66$ & $360,30 \pm 48,25$ & $*$ \\
Oleic (C18:1n - 9) & $443,87 \pm 71,05$ & $713,40 \pm 108,13$ & $*$ \\
Linoleic (C18:2n - 6) & $40,30 \pm 7,65$ & $43,90 \pm 6,50$ & NS \\
\hline
\end{tabular}

$\mathrm{NS}=$ not significant $(\mathrm{P}>0.05) ; * \mathrm{P}$ value $<0.05 ; * * \mathrm{P}$ value $<0.01$

Table 7. Means and standard errors for sensory attributes evaluated by consumers of lamb meat in two feeding systems

\begin{tabular}{|c|c|c|c|}
\hline Characteristics & Unweaned lambs & Supplemented weaned lambs & $\mathrm{P}$ value \\
\hline Color & $6.53 \pm 0.70$ & $6.53 \pm 0.73$ & NS \\
\hline Tenderness & $7.80 \pm 0.56$ & $7.71 \pm 0.55$ & NS \\
\hline Flavor & $7.32 \pm 0.63$ & $7.32 \pm 0.65$ & NS \\
\hline Overall liking & $7.41 \pm 1.19$ & $7.38 \pm 0.55$ & NS \\
\hline
\end{tabular}

$\mathrm{NS}=$ not significant $(\mathrm{P}>0.05) ; * \mathrm{P}$ value $<0.05 ; * * \mathrm{P}$ value $<0.01$

Evaluation with structured scale of nine points according to Dutcosky (2014): (1= 'strongly disliked'; 2 = 'disliked'; 3 = 'moderately disliked'; 4 = 'slightly disliked'; $5=$ indifferent; $6=$ 'slightly liked'; 7 = 'moderately liked'; 8 = 'liked'; 9 = 'strongly liked')

The myristic (C14:0) and palmitic acids (C16:0) are responsible for increasing plasma cholesterol (Santos et al., 2013), causing concern to consumers. In this study, myristic (C14:0) and palmitic acids (C16:0) had no significant difference in meat from both systems. Likewise, Panea et al. (2011) also found no significant effect on myristic acid (C14:0) content in the meat of lambs raised under different feeding systems (pasture, grazing + supplement, and confinement). 
In this study, the oleic acid $(\mathrm{C} 18: 1)$ content was affected $(p<0.05)$ by the feeding system and it was found as the highest values among the identified FA. Similarly, Velasco et al (2004) observed higher oleic acid in the meat of lambs fed with grains and cereals than in grazing animals. Bas \& Morand-Fehr (2000) found higher percentage of myristic acid (C14:0), palmitic acid (C16:0) and oleic acid (C18:1) and lower proportion of stearic acid (C18:0), linoleic $(\mathrm{C} 18: 2)$ and linolenic acid $(\mathrm{C} 18: 3)$ in the meat of suckling lambs than of weaned lambs. The ewe's milk is rich in myristic (C14:0) and palmitic acid (C16:0). We highlight that the weaned lambs were fed with concentrate diet after weaning that altered this result. According to Bas and Morand-Fehr (2000), after weaning, the percentage of myristic acid (C14:0) gradually decreases and the percentage of long chain saturated FA increases, probably due to the lower percentage of short and medium chain FA and the high percentage of long chain acids in the post-wean diet. In fact, meat from supplemented weaned lambs showed higher long chain FA content (stearic acid-C18:0, oleic acid-C18:1 and linolenic acid-C18:3) than suckling lambs.

The linoleic acid (C18:2n - 6) content also did not differ $(p>0.05)$ in lamb meat, even with the concentrate supplementation. Similarly, Fernandes et al. (2010) studying four feeding systems (weaned in pasture, suckling lambs in pasture, creep feeding, and weaned in feedlot) did not find differences in linoleic acid (C18:2n - 6) content in lamb meat.

The scores for sensory attributes in lamb meat were similar among the feeding systems $(p>$ 0.05; Table 6). Despite the presence of concentrate in the diet of weaned lambs, there was no difference in sensory characteristics. Similarly, Tonetto et al. (2004) found no differences in the juiciness and tenderness of meat from lambs reared in three different feeding systems (pasture with supplement, ryegrass, and confinement). Otherwise, Sañudo et al. (1998a) reported improved sensorial quality of the meat flavor in milk-fed, suckling animals. Cañeque et al. (1989) stated that the presence of concentrate can modify the meat taste and flavor due to the change in the fat lipid composition. However, in the present study, the proportion of FA type was similar, causing no influence on the meat flavor.

Scores for overall liking of lamb meat were above 7.0 for both treatments, indicating a 'moderately liked' to 'liked' perception of meat by the consumers (Dutcosky, 2014). Overall liking is a mixture of flavor and tenderness scores, as well as other sensations that consumers perceive when they taste the meat lamb samples (Guerrero et al., 2013).

As discussed by Guerrero et al. (2013), the effect of the production system on the meat quality has been dealt with from different points of view, as it may be considered an effect from multi-causal factors, including feeding, for instance, the breed, the previous management to finishing time, and mainly feeding and duration of the finishing period. It is, therefore, highly important to consider differences among consumers. A market study has to be carried out, because consumers from different countries and different regions within the same country may have differences in lamb meat preferences. 


\section{Conclusions}

Lamb meat from both feeding systems showed good meat quality and high sensory acceptance. Early weaning and supplementation seem to be a better choice for producing lambs in the winter-spring pasture and for integrated livestock crop areas in subtropical conditions, if the cost of the concentrate is favorable. It made better carcass and meat traits which could improve the payment to the farmers, as also improve the market value of lambs. This feeding system still favors the body condition of the ewes in the next breeding season.

\section{Acknowledgments}

The authors gratefully acknowledge the financial support received from the National Council for Scientific and Technological Development (Edital CT Agronegócio 17/2010). Alda L. G. Monteiro is member of the MARCARNE network, funded by CYTED (116RT0503).

\section{Source of research funding}

National Council for Scientific and Technological Development (Edital CT Agronegócio 17/2010).

\section{Events where the study was partially presented}

Costa G, Monteiro ALG, Macedo REF, Hentz F, Silva CJA, Prado O, Bridi AM, Scucato T. Lamb meat quality in systems of production in South of Brazil. 51 ${ }^{\mathrm{a}}$ Reunião Anual da Sociedade Brasileira de Zootecnia, 2014.

Costa G, Monteiro ALG, Macedo REF, Fernandes MAM, Fillus AM, Peres MTP, Salgado FR, Scucato T. Microorganisms in lamb carcasses from slaughterhouse in the State of Parana BR. 51 ${ }^{\text {a }}$ Reunião Anual da Sociedade Brasileira de Zootecnia, 2014.

Scucato T, Costa G, Monteiro ALG, Debortoli EC, Macedo REF, Taconeli CA, Silva BHC. Qualidade sensorial da carne de cordeiros produzida em dois sistemas de terminação em pastagem de inverno. 52 ${ }^{\mathrm{a}}$ Reunião Anual da Sociedade Brasileira de Zootecnia, 2015.

\section{References}

Alvarez, J. M., Mayo, A., García, V. J. C., Giorgetti, H., Rodríguez, G., \& Roa, M. (2013). Calidad de carne de corderos pesados alimentados en confinamiento. In: Pordo, AJ. Avances en calidad de carne de ovinos, caprinos, porcinos y aves. Compilado de una década de estudios en INTA: Programa Carnes. Anguil (LP): Instituto Nacional de Tecnología Agropecuaria; p. pages 17-21.

AOAC (Association of official analytical chemists). (1984). Official methods of analysis (14th edn). Washington (DC): AOAC.

AOAC (Association of official analytical chemists). (2000). Official Methods of Analysis of the Association of Official Analytical Chemists (17th edn). Gaithersburg (MD): AOAC.

Arruda, P. C. L. de, Pereira, E. S., Pimentel, P. G., Bomfim, M. A. D., Mizubuti, I. Y., Ribeiro, E. L. de A, ... Filho, J. G. L. R. (2012). Perfil de ácidos graxos no Longissimus dorsi de 
cordeiros Santa Inês alimentados com diferentes níveis energéticos. Semina: Ciências Agrárias. 33(3), 1229-1240. https://doi.org/10.5433/1679-0359.2012v33n3p1229

ASTM (American Society for Testing and Material). (2001). Standard practice for computing the colors of objects by using the CIE system. Pennsylvania (US): ASTM International.

Barbut, S. (1996). Estimates and detection of the PSE problem in young turkey breast meat. Canadian Journal of Animal Science, 76, 455-457. https://doi.org/10.4141/cjas96-066

Bas, P., \& Morand-Fehr, P. (2000). Effect of nutritional factors on fatty acid composition of lamb fat deposits. Livestock Production Science. 64, 61-79.

https://doi.org/10.1016/S0301-6226(00)00176-7

Boughalmi, A., \& Araba, A. (2016). Effect of feed management from grassland to concentrate feed on growth, carcass characteristics, meat quality and fatty acid profile of Tinahdite lamb breed. Small Ruminant Research. 44, 158-163.

https://doi.org/10.1016/j.smallrumres.2016.09.013

Brasil. (2001). Agência Nacional de Vigilância Sanitária. Resolução RDC n. 12, de 2 de janeiro de 2001. Aprova o Regulamento Técnico sobre padrões microbiológicos para alimentos. Brasília (DF): Diário Oficial da União.

Burms, J. C., Lippke, H., \& Fischer, D. S. (1989). The relationship of herbage mass and characteristics to animal responses in grazing experiments. In: Marten GC. Grazing Research: Design, Methodology and Analysis. Madison (WI): CSSA; p. pages 7-20.

Cañeque, V., \& Sañudo, C. (2000). Metodología para el estudio de la calidad de la canal y de la carne en ruminantes. Madrid (ES): Instituto de Investigación y Tecnología Agraria y Alimentaria.

Cañeque, V., Huidobro, F. R., \& Dolz, J. F. (1989). Producción de carne de cordero. Madrid (ES): Ministerio de Agricultura Pesca y Alimentación.

Carvalho, S., Brochier, M. A., Pivato, J., Teixeira, R. C., \& Kieling, R. (2007). Ganho de peso, características da carcaça e componentes não carcaça de cordeiros da raça Texel terminados em diferentes sistemas alimentares. Ciência Rural, 37, 821-827.

https://doi.org/10.1590/S0103-84782007000300034

Carvalho, S., Vergueiro, A., Kieling, R., Teixeira, R. C., Pivato, J., Viero, R., \& Cruz, N. A. da. (2006). Desempenho e caraterísticas da carcaça de cordeiros mantidos em pastem de Tifton-85 e suplementados com diferentes níveis de concentrado. Revista Brasileira de Agrociência, 12(3), 357-361.

Chestnutt, D. M. B. (1994). Effect of lamb growth rate and growth pattern on carcass fat levels. Animal Production, 58, 77-85. https://doi.org/10.1017/S0003356100007108

Chikwanha, O. C., Vahmani, P., Muchenje, V., Duganb, M. E. R., \& Mapiye, C. (2018). Nutritional enhancement of sheep meat fatty acid profile for human health and wellbeing. Food Research International, 104, 25-38. https://doi.org/10.1016/j.foodres.2017.05.005 
Colomer-Rocher, F., Morand-Fehr, P., Kirton, A. H., Belenguer, R. D., \& Alfranca, I. S. (1988). Metodos normalizados para el estudio de los caracteres cuantitativos y cualitativos de las canales caprinas y ovinas $n^{\circ} 17$. Madrid (ES): Cadernos INIA.

Dutcosky, S. D. (2014). Análise sensorial de alimentos. Curitiba (PR): Champagnat.

Enser, M., Hallett, K., Hewett, B., Fursey, G. A., \& Wood, J. D. (1996). Fatty acid composition of English beef, lamb and pork at retail. Meat Science, 42, 443-456. https://doi.org/10.1016/0309-1740(95)00037-2

Fernandes, M. A. M., Monteiro, A. L. G,, Poli, C. H. E. C., Barros, C. S., Almeida, R., \& Ribeiro, T. M. D. (2010). Composição tecidual da carcaça e perfil de ácidos graxos da carne de cordeiros terminados a pasto ou em confinamento. Revista Brasileira de Zootecnia, 39, 1600-1609. https://doi.org/10.1590/S1516-35982010000700029

Fernandes, S. R., Salgado, J. A., Natel, A. S., Monteiro, A. L. G., Prado, O. R., Barros, C. S., \& Fernandes, M. A. M. (2014). Performance, carcass traits and costs of Suffolk lambs finishing systems with early weaning and controlled suckling. Revista Ceres, 61(2), 184-192. https://doi.org/10.1590/S0034-737X2014000200005

Firestone, P. (1998). Official methods and recommended practices of the American Oil Chemists Society (5th edn) (Method Ce-1F-96). Champaign (IL): AOCS.

Fonseca, M. P., Geraseev, L. C., Rufino, L. M. A., Garcia, I. F. F., Souza, R. M., \& Costa, N. P. P. (2012). Use of macaúba cake replacing corn on carcass characteristics and body measurements of Santa Inês lambs Revista Brasileira de Zootecnia, 41(5), 1231-1235. https://doi.org/10.1590/S1516-35982012000500021

Food Advisory Committee. (1990). Report on Review of Food Labelling and Advertising. London (UK): Stationery Office.

Guerrero, A., Valero, M. V., Campo, M. M., \& Sañudo, C. (2013). Some factors that affect ruminant meat quality: from the farm to the fork. Review. Acta Scientiarum Animal Science, 35, 335-347. https://doi.org/10.4025/actascianimsci.v35i4.21756

Hartman, L., \& Lago, R. C. A. (1973). Rapid preparation of fatty acid methyl from lipids. Laboratory practice. 22, 475-476.

Hashimoto, J. H., Osório, J. C. S., Osório, M. T. M., Bonacina, M. S., Lehmen, R. I., \& Pedroso, C. E. S. (2012). Qualidade de carcaça, desenvolvimento regional e tecidual de cordeiros terminados em três sistemas. Revista Brasileira de Zootecnia, 41, 438-448. https://doi.org/10.1590/S1516-35982012000200029

Hentz, F., Prado, O. R., Monteiro, A. L. G., Souza, D. F., Ferreira, F. S., \& Filho, I. R. B. (2012). Influência de sistemas de terminação de cordeiros sobre a produção e condição sanitária das ovelhas em pastagem. Archives of Veterinary Science, 17, 1-9.

https://doi.org/10.5380/avs.v17i3.20092

Houdijk, J. G. M. (2012). Differential effects of protein and energy scarcity on resistance to nematode parasites. Small Ruminant Research, 103, 41-49. 
https://doi.org/10.1016/j.smallrumres.2011.10.017

Huidobro, de R., Cañeque, V., Onega, E., \& Velasco, S. (2000). Morfologia de la canal ovina. In: Cañeque V, Sañudo C. Metodología para el estudio de la calidad de la canal y de la carne em rumiantes. Madrid (ES): Instituto Nacional de Investigación y Tecnología Agraria e Alimentaria. p. 81-102.

Hunter, J. E., Zhang, J., \& Kris-Etherton, P. M. (2010). Cardiovascular disease risk of dietary stearic acid compared with trans, other saturated, and unsaturated fatty acids: A systematic review. The American Journal of Clinical Nutrition, 91, 46-63.

https://doi.org/10.3945/ajen.2009.27661

Kearl, L. C. (1982). Nutrient requirements of ruminants in developing countries. Logan (UT): International Feedstuff Institute.

Lee, M. R. F., Evans, P. R., Nute, G. R., Richardson, R. I., \& Scollan, N. D. (2009). A comparison between red clover silage and grass silage feeding on fatty acid composition, meat stability and sensory quality of the M. longissimus muscle of dairy cull cows. Meat Science, 81, 738-744. https://doi.org/10.1016/j.meatsci.2008.11.016

Montossi, F. (2007). I. Visión Estratégica: La contribución del este proyecto a la mejora de la competitividade de la cadena cárnica del Uruguay. In Montossi F, Sañudo C. Diferenciación y Valorización de la Carne Ovina y Bovina del Uruguay en Europa: Influencia de Sistemas de Producción sobre Bienestar Animal, Atributos Sensoriales, Aceptabilidad y Percepción de Consumidores y Salud Humana. Tacuarembó (UR): Instituto Nacional de Investigacion Agropecuaria. p. pages 1-4. Serie Tecnica 168.

Morgan, J. B., Wheeler, T. L., Koohmaraie, M., Savell, J. W., \& Crouse, J. D. (1993). Meat tenderness and the calpain proteolytic system in Longissimus muscle of young bulls and steers. Journal of Animal Science, 71, 1471-1476. https://doi.org/10.2527/1993.7161471x

Morris, S. T., \& Kenyon, P.R. (2014). Intensive sheep and beef production from pasture - A New Zealand perspective of concerns, opportunities and challenges. Meat Science, 98(3), 330-335. https://doi.org/10.1016/j.meatsci.2014.06.011

Mott, G. O., \& Lucas, H. L. (1952). The design, conduct and interpretation of grazing trials on cultivated and improved pastures. In: Wagner RE et al. Proceedings of 6th International Grassland Congress. Pennsylvania (USA): Penn State College Press. p. pages 1380-1385.

Muela, E., Sañudo, C., Campo, M. M., Medel, I., \& Beltrán, J. A. (2010). Effects of cooling temperature and hot carcass weight on the quality of lamb. Meat Science, 84(1), 101-107. https://doi.org/10.1016/j.meatsci.2009.08.020

NRC - National Research Council. (2007). Nutrient Requirements of Small Ruminants: Sheep, Goats, Cervids and New World Camelids. Washington (D.C.): National Academies Press.

Osório, J. C. da S., Osório, M. T. M., Fernandes, A. R. M., \& Vargas Junior, F. M. de. (2014). Produção e Qualidade da Carne Ovina. In: Selaive AB, Osório JCS. Produção de Ovinos no 
Brasil. São Paulo (SP): Roca. p. pages 399-446.

Owens, F. N., Gill, D. R., Secrist, D. S., \& Coleman, S. W. (1995). Review of some aspects of growth and development of feedlot cattle. Journal of Animal Science, 73(10), 3152-72. https://doi.org/10.2527/1995.73103152x

Panea, B., Carrasco, S., Ripoll, G., \& Joy, M. (2011). Diversification on feeding systems for light lambs: sensory characteristics and chemical composition of meat. Spanish Journal of Agriculture Research, 9(1), 74-85. https://doi.org/10.5424/sjar/20110901-089-10

Pla, M. (2000). Medida de la capacidad de retención de agua. In: Cañeque V, Sañudo C. Metodología para el estudio de la calidad de la canal y de la carne em rumiantes. Madrid (ES): Instituto Nacional de Investigación y Tecnología Agraria y Alimentaria. p. pages 173-179.

R Development Core Team (2012). R: a language and environment for statistical computing. Vienna (AU): R Foundation for Statistical Computing.

Ribeiro, T. C. D., Monteiro, A. L. G., Prado, O. R., Natel, A. S., Salgado, J. A., Piazzetta H. V. L., \& Fernandes, S. R. (2009). Desempenho animal e características das carcaças de cordeiros em quatro sistemas de produção. Revista Brasileira de Saúde e Produção Animal. 10, 366-378.

Ricardo, H. A., Fernandes, A. R. M., Mendes, L. C. N., Oliveira, M. A. G., Protes, V. M., Scatena, E. M., \& Alves, L. G. C. (2015). Carcass traits and meat quality differences between a traditional and an intensive production model of market lambs in Brazil: Preliminary investigation. Small Ruminant Research, 130, 141-145.

https://doi.org/10.1016/j.smallrumres.2015.07.007

Rizzi, L., Simioli, M., Sardi, L., \& Monetti, P. G. (2002). Carcass quality, meat chemical and fatty acid composition of lambs fed diets containing extruded soybeans and sunflower seeds. Animal Feed Science and Technology, 97, 103-114.

https://doi.org/10.1016/S0377-8401(01)00344-3

Russell, A. J. F., Doney, J. M., \& Gunn, R. G. (1969). Subjective assessment of body fat in live sheep. Journal of Agricultural Science, 72, 451-454.

https://doi.org/10.1017/S0021859600024874

Safari, E., Nogarty, N. M., Ferrier, G. R., Hopkins, D. L., \& Gilmour, A. (2001). Diverse lamb genotypes. 3. Eating quality and the relationship between its objective measurement and sensory assessment. Meat Science, 57, 153-159.

https://doi.org/10.1016/S0309-1740(00)00087-5

Salgado, J. A., \& Santos, C. P. (2016). Overview of anthelmintic resistance of gastrointestinal nematodes of small ruminants in Brazil. Brazilian Journal of Vet. Parasitology, 25(1), 3-17. https://doi.org/10.1590/S1984-29612016008

Santos, R. D., Gabliardi, A. C. M., Xavier, H. T., Magnoni, C. D., Caassani, R., Lottenberg, A. M. P., ... Ramos, S. (2013). Sociedade Brasileira de Cardiologia. I Diretriz sobre o consumo de Gorduras e Saúde Cardiovascular. Arquivos Brasileiros de Cardiologia, 100, 1-40. 
https://doi.org/10.5935/abc.2013S003

Santos-Silva, J., Mendes, I. A., \& Bessa, R. J. B. (2002). The effect of genotype, feeding system and slaughter weight on the quality of light lambs 1.Growth, carcass composition and meat quality. Livestock Production Science, 76, 17-25.

https://doi.org/10.1016/S0301-6226(01)00334-7

Sañudo, A. C. (2008). Qualidade da carcaça e da carne ovina e caprina em face ao desenvolvimento da percepção do consumidor. Revista Brasileira de Zootecnia, 37, 143-160. https://doi.org/10.1590/S1516-35982008001300018

Sañudo, C., \& Sierra, I. (1986). Calidad de la canal em la espécie ovina. Barcelona (ES), Ovino One SA.

Sañudo, C., Alfonso, M., San, J. R., Thorkelsson, G., Valdimarsdottir, T., Zygoyiannis, D., ... Fisher, A. V. (2007). Regional variation in the hedonic evaluation of lamb meat from diverse production systems by consumers in six European countries. Meat Science, 46, 610-621. https://doi.org/10.1016/j.meatsci.2006.09.009

Sañudo, C., Campo, M. M., Sierra, I., María, G. A., Olleta, J L., \& Santolaria, P. (1997). Breed effect on carcass and meat quality of suckling lambs. Meat Science, 46, 357-365.

https://doi.org/10.1016/S0309-1740(97)00030-2

Sañudo, C., Sanchez, A., \& Alfonso, M. (1998a). Small ruminant production systems and factors affecting lamb meat quality. Meat Science, 49(1), 529-564.

https://doi.org/10.1016/S0309-1740(98)00073-4

Sañudo, C., Santolaria, M. P., María, G., Osorio, M., \& Sierra, I. (1996). Influence of Carcass Weight on Instrumental and Sensory Lamb Meat Quality in Intensive Production Systems. Meat Science, 42, 195-202. https://doi.org/10.1016/0309-1740(95)00026-7

Sañudo, C., Sierra, I., Olleta, J. L., Martin, L., Campo, M. M., Santolaria, P., ... Nute, G. R. (1998b). Influence of weaning on carcass quality, fatty acid composition and meat quality in intensive lamb production systems. Animal Science, 66, 175-187.

https://doi.org/10.1017/S1357729800008948

Shackelford, S. D., Wheeler, T. L., \& Koohmaraie, M. (1997). Effect of the callipyge phenotype and cooking method on tenderness of several major lamb muscles. Journal of Animal Science, 75, 2100-2105. https://doi.org/10.2527/1997.7582100x

Shapiro, S. S., \& Wilk, M. B. (1965). An analysis of variance test for normality (complete samples). Biometry, 52, 591-611. https://doi.org/10.1093/biomet/52.3-4.591

Tonetto, C. J., Pires, C. C., Müller, L., Rocha, M. G. da, Frescura, R. B. M., \& Kippert, C. J. (2004). Rendimentos de Cortes da Carcaça, Características da Carne e Componentes do Peso Vivo em Cordeiros Terminados em Três Sistemas de Alimentação. Revista Brasileira de Zootecnia, 33, 234-241. https://doi.org/10.1590/S1516-35982004000100027

Van Soest, P. J., Robertson, J. B., \& Lewis, B. A. (1991). Methods for dietary fiber, and no 
starch polysaccharides in relation animal nutrition. Journal of Dairy Science, 74(10), 3583-3587. https://doi.org/10.3168/jds.S0022-0302(91)78551-2

Velasco, S., Cañeque, V., Lauzurica, S., Pérez, C., \& Huidobro, F. (2004). Effect of different feeds on meat quality and fatty acid composition of lambs fattened at pasture. Meat Science, 66, 457- 465. https://doi.org/10.1016/S0309-1740(03)00134-7

Weiss, W. P., Conrad, H. R., \& St. Pierre, N. R. (1992). A theoretically-based model for predicting total digestible nutrient values of forages and concentrates. Anim. Feed Sci. Technol., 39, 95-110. https://doi.org/10.1016/0377-8401(92)90034-4

Young, O A., West, J., Hart, A. L., \& van Otterdijk, F. F. (2004). A method for early determination of meat ultimate pH. Meat Science, 66, 493-498. https://doi.org/10.1016/S0309-1740(03)00140-2

\section{Copyright Disclaimer}

Copyright for this article is retained by the author(s), with first publication rights granted to the journal.

This is an open-access article distributed under the terms and conditions of the Creative Commons Attribution license (http://creativecommons.org/licenses/by/4.0/). 